\title{
Recent Progress in Low-Impact Development in South Korea: Water-Management Policies, Challenges and Opportunities
}

\author{
Muhammad Shafique ${ }^{1,2}$ (D) and Reeho Kim ${ }^{1,2, *}$ \\ 1 Department of Smart City and Construction Engineering, Korea Institute of Civil Engineering and Building \\ Technology, University of Science \& Technology (UST), 217, Gajeong-ro, Yuseong-gu, Daejeon 34113, Korea; \\ shafique@ust.ac.kr \\ 2 Environmental \& Plant Engineering Research Institute, Korea Institute of Civil Engineering and Building \\ Technology, 83, Goyangdae-ro, Ilsanseo-gu, Gyeonggi-do, Goyang-si 10223, Korea \\ * Correspondence: rhkim@kict.re.kr; Tel.: +82-31-9100-291
}

Received: 19 March 2018; Accepted: 2 April 2018; Published: 6 April 2018

\begin{abstract}
For the past few decades, rapid urban development and climate change has caused many meteorological disasters (flooding, droughts, and heat waves) in South Korea. The current stormwater management system (gray infrastructure) is based on the pipe networks, which is not an effective method to control flash flooding problems during big rain events. Therefore, there is a need to find a more sustainable stormwater-management system that can have the ability to solve these water-related problems in urban areas. Low-impact development (LID)/green infrastructure (GI) practices are an effective approach to solving the adverse effects of urbanization and to addressing climate change. This paper reviews national water-management policies which were selected for flood and environmental protection from 1960 to 2017. Research results of applied LID practices in Korea also show that these practices are useful for stormwater management in urban areas. The dominating challenges identified are: lack of proper knowledge for implementing LID practices; uncertainties in the benefits of LID/GI practices; and lack of cooperation and collaboration between different agencies for the expansion of LID projects. Finally, some opportunities for LID/GI practices in Korea are also described.
\end{abstract}

Keywords: low-impact developments; green infrastructure; stormwater management; cooperation; collaboration; flash flooding

\section{Introduction}

Recently, water management has become increasingly challenging in urban areas [1]. Nowadays, population growth, climate change and limited available resources are causing severe challenges around the globe [2,3]. During the last few decades, urbanization and climate change have contributed to many meteorological disasters such as typhoons, urban floods and droughts in South Korea [3], and the country was not expecting these problems or ready to cope with them. The largest meteorological disaster in the 20th century occurred in 1994. Different heat waves and typhoons caused many causalities (3384) and property damage around the different parts of the country [4,5]. In September 2010, heavy rain (>100 mm of rain per hour) in Seoul, Gyeonggi province and Yeongseo province caused much damage, including the inundation and closure of subways. In 2012, Gangnam station, Seoul, suffered a flash flood. In August 2014 at Halla Mountain, Jeju, typhoon "Nakri" delivered precipitation of more than $1000 \mathrm{~mm}$ over the day [5]. In addition, a two-year drought occurred in South Korea (2014 and 2015), posing severe threats to human as well as animal life in the country [6]. 
The total population of South Korea ascended to 51.32 million at the end of 2014 with approximately $50 \%$ crowding in the capital city Seoul [7,8]. As a result of economic development in South Korea, the urbanization rate of the country has increased tremendously. In the capital, Seoul, impervious areas increased from $7.8 \%$ to $47.7 \%$ from 1962 to 2010 , resulting in surface runoff increasing from $10.6 \%$ to $51.9 \%$. Figure 1 shows the urban population increase of the three above countries with the passage of time. As seen from Figure 1, the urbanization rate of South Korea from 1960-2016 exceeded that of both China and the United States of America; a development considered desirable by the South Korea government. These changes in the Korean peninsula altered hydrological water cycles and caused many water-related problems. The typical issues of urbanization and climate change include urban flooding, droughts and heat-island phenomena which would directly affect society (health, social stability and economic development).

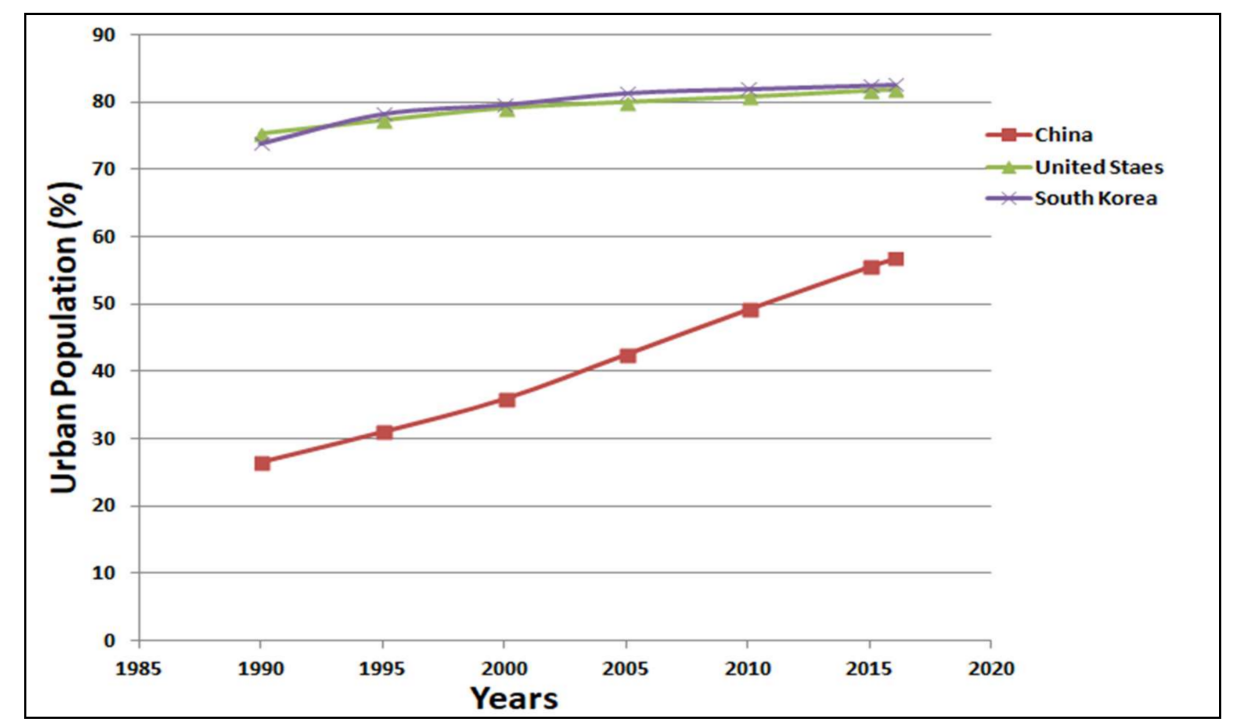

Figure 1. Urban development in the Republic of Korea compared to China and the United States, 1960-2016 [9].

In the above circumstances, it is necessary to take corrective action. The installation of low-impact development (LID) or green infrastructure (GI) practices is a method to mitigate the adverse impact of increased runoff caused by urbanization. LID or GI practices help to achieve both development and environmental protection by mimicking the natural hydrology of an area [10-12].

The trend toward LID research arose from the rising requirement of LID engineers to develop modern and sustainable stormwater-management systems that have the capability and capacity to reduce water-related problems while maintaining the natural hydrology of an area. For example, grass swale, blue roof and rain gardens have been used to control, stormwater management as well as to maintain the natural hydrological condition of an area in a safe and sustainable way [12-14].

Unluckily, the current stormwater management system in use comes with compromises and hence limited benefits when considering today's demand to address environmental, economic, and sustainable concerns. For instance, to develop a sustainable stormwater system, different best-management practices are retrofitted to existing areas to obtain a combination of benefits that control flash flooding and water-quality degradation problems [15,16].

By contrast, GI practices are capable of improving the environmental and hydrological conditions of an area while considering the economic requisites. Many studies have shown that LID gives multiple benefits by increasing the infiltration of water to the ground $[17,18]$ and reducing runoff volume and pollutant loadings [18]. LID practices are useful for controlling runoff, infiltrating water into the ground, and evaporating resulting water in order to maintain the natural hydrological cycle of an 
area $[19,20]$. However, there is a need to develop new cost-effective LID/GI technology that can have multiple benefits, such as heat waves, runoff reduction, and rainwater storage and contribute to maintaining the natural environment of an area.

\section{Concept of Low-Impact Development/Green Infrastructure (LID/GI) Practices}

LID practices emphasize the use of small-scale, natural drainage features integrated throughout the area to slow and reduce runoff and restore infiltration and evapo-transpiration in urban areas. As a result of this, these practices mitigate the adverse effects of urbanization such as flash flooding, drought and water-quality degradation problems [19-22]. Figure 2, shows the concept of the LID practice that is followed by the South Korean government to make cities sustainable as compared to traditional stormwater-management practices.

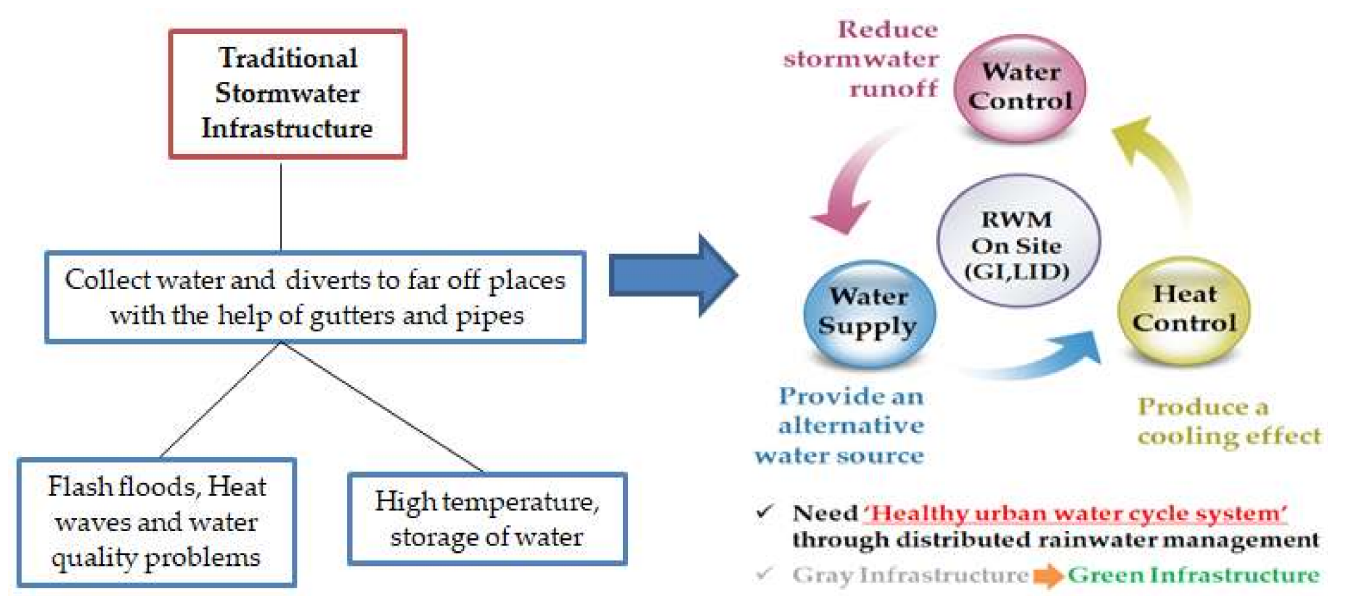

Figure 2. The concept of conversion of gray infrastructure to green infrastructure, adopted by the South Korean government (own illustration).

LID/GI are the terms that have been adopted to achieve healthy urban water cities in different countries such as Germany, USA and Japan, as shown in Table 1 [16,22,23]. Similar technologies under different names are described such as decentralized urban design (DUD) in Germany, sustainable urban drainage system (SUDS) in the UK, water-sensitive urban design (WSUD) in Australia, well-balanced hydrological system (WBHS) in Japan, sponge city in China, and healthy water-cycle city or rain city in South Korea [3,22,24-29]. The main objective of all these practices is to manage rainwater through a distributed approach. Nowadays, China is using LID/GI practices in 32 cities [30,31]. The successful case studies of LID practices include the central zone of the Olympic Park and the central business district (CBD) core Area of Choayang District in Beijing [29]. In South Korea, the government is making numerous efforts to develop the rain city and rain village projects that will help to make urban water-management safe.

For the application of LID practices, different terms such as healthy water-cycle city and rain city were used in South Korea. The rain city is based on the concept of managing the rainwater as much as possible in an area through storage, infiltration and evapo-transpiration. The healthy water -ycle city term refers to a safe and sustainable city that tries to maintain a natural water cycle through the application of best-management practices [31].

The main goal of this study was to give an overview of water-management policies at the national and local levels, to identify challenges, and to provide some solid suggestions to overcome these challenges.

The main objectives of this paper are as follows: (1) provide insights into the LID technology concept; (2) present a detailed overview of water-management policies in South Korea; (3) explain in detail the recent challenges to LID in South Korea; (4) describe the future opportunities for LID practices in South Korea. 
Table 1. Origin of the terms referring to low-impact development (LID) for urban water-management in different countries.

\begin{tabular}{|c|c|c|c|c|c|c|c|}
\hline Country & Germany & United Kingdom & USA & Australia & Japan & China & South Korea \\
\hline Concept & $\begin{array}{l}\text { Decentralized Urban } \\
\text { Design (DUD) }\end{array}$ & $\begin{array}{c}\text { Sustainable Urban } \\
\text { Drainage system (SUDS) }\end{array}$ & $\begin{array}{c}\text { Low Impact } \\
\text { Development/ Green } \\
\text { Infrastructure (LID/GI) }\end{array}$ & $\begin{array}{c}\text { Water Sensitive Urban } \\
\text { Design Water Sensitive } \\
\text { City (WSUD) }\end{array}$ & $\begin{array}{c}\text { Well-balanced } \\
\text { Hydrological System } \\
\text { (WBHS) }\end{array}$ & $\begin{array}{l}\text { Sponge City for } \\
\text { Flood Control (SC) }\end{array}$ & $\begin{array}{l}\text { Healthy Water } \\
\text { Cycle City, } \\
\text { Rain City, } \\
\text { Moist City } \\
\text { (HWC2) }\end{array}$ \\
\hline \multirow{4}{*}{ Characteristics } & \multirow{2}{*}{$\begin{array}{c}\text { Decentralized } \\
\text { rainwater management }\end{array}$} & \multirow{2}{*}{$\begin{array}{l}\text { Integrated design on } \\
\text { quantity, quality } \\
\text { and amenity }\end{array}$} & \multirow{2}{*}{$\begin{array}{l}\text { Management of pollution } \\
\text { sources \& rainwater } \\
\text { management based on } \\
\text { green land }\end{array}$} & \multirow{2}{*}{$\begin{array}{l}\text { Rainwater management } \\
\text { adaptable to } \\
\text { climate change }\end{array}$} & \multirow{2}{*}{$\begin{array}{l}\text { Applied as one unit of } \\
\text { river basin }\end{array}$} & \multirow{4}{*}{$\begin{array}{l}\text { A sponge city is } \\
\text { one that can hold, } \\
\text { clean, drain water } \\
\text { in a natural way } \\
\text { using an ecological } \\
\text { approach }\end{array}$} & $\begin{array}{l}\text { Green stormwater } \\
\text { infrastructure }\end{array}$ \\
\hline & & & & & & & $\begin{array}{l}\text { Zero stormwater } \\
\text { discharge projects }\end{array}$ \\
\hline & \multirow{2}{*}{$\begin{array}{l}\text { Management and using } \\
\text { of storm-water runoff }\end{array}$} & \multirow{2}{*}{$\begin{array}{c}\text { Site management } \\
\text { (design, mainten-ance \& } \\
\text { education) }\end{array}$} & \multirow{2}{*}{ BMPs/LID/GI } & \multirow{2}{*}{$\begin{array}{l}\text { Management and use of } \\
\text { storm water runoff }\end{array}$} & \multirow{2}{*}{$\begin{array}{l}\text { Well-balanced among } \\
\text { flood control, water use } \\
\text { and aqua-environ-ment }\end{array}$} & & Rain City \\
\hline & & & & & & & Rain Village \\
\hline
\end{tabular}




\section{Materials and Methods}

This study consists of a literature review, information collection and field studies in LID projects, the research results of applied LID facilities in South Korea, and information collected from the public. Previous water-management policies were studied from past laws and legislation. For this purpose, different government reports were analyzed and studied. All the LID projects in the Seoul metropolitan area were included in this study. Information collected in this study related to the current and future challenges to further expanding LID programs. It was designed to ascertain the quantitative as well as qualitative benefits of LID projects and how the above challenges can be overcome.

All the data and information were collected from sources such as reviewing LID projects and annual result reports, field research reports, and literature reviews. In addition, a research team also conducted field trips to collect real field data from Seoul LID projects from 2013 to May 2017.

\section{Results and Discussion}

\subsection{Water-Management Policies in South Korea}

\subsubsection{National Level}

Figure 3 gives an overview of water-management policies and different water laws implemented by the South Korean government. In South Korea, different authorities are involved in establishing water-management laws which include MLTM (Ministry of Land, Transport, and Marine Affairs), MoE (Ministry of Environment), MIFAFF (Ministry for Food, Agriculture, Forest and Fisheries), and K-Water (previously named Korea Water Resources Corporation). These authorities usually draw up laws and acts related to water in South Korea. A Korean water-management plan was initiated with the promulgation of River Basin Law in 1961; the biggest tasks were flood reduction and restoration of the water supply for multiple purposes, including energy production, agriculture and the potable water supply [15,32]. In 1967, the Korean government established the Ten-Year Comprehensive Water Resource Development Plan (1966-1975) and the Multipurpose Dam Act (MDA) of 1966 [32,33]. The main purpose of these laws was to store water in big dams and use it for different purposes like hydropower generation, irrigation and water supply.

In the 1970s, after industrialization in the country, the top priority was to secure a sufficient amount of water for industry as well as for agriculture [33]. The River Basin Law was revised in 1971, and a new comprehensive development plan for four major rivers was developed. The main purpose of this new plan was to change single dams to multipurpose dams that can give multiple benefits such as water supply, reduce floods, restore surface water, and hydropower generation etc. [32]. Rapid urbanization and industrialization demanded more water for industrial as well as urban areas. During the 1980s, South Korea made various efforts to improve the quality of sewage water through sewage-treatment plants. However, the sewage-treatment plant operation needs proper attention and working mechanisms to avoid undesirable incidents. The first incident was the phenol contamination that occurred in Daegu in 1991, which led to demands for more attention to environmental preservation. Therefore, later developments included environment preservation as an essential element. During the period 1960-2007, most of the laws were introduced for the flooding and environmental protection. Other laws, i.e., a law on management of drinking water, a framework act on national land, a law on countermeasures against natural disasters and a water-quality ecosystem conservation act also follow the same concept of flood and environmental protection.

After the industrialization in South Korea, the emission of $\mathrm{CO}_{2}$ was extremely high. Therefore, to minimize the emission of $\mathrm{CO}_{2}$, the government introduced a new law of Green Standards for Energy and Environmental Design (GSEED). The main idea of this law includes the application of green technologies which can adapt to climate change like the green roof, solar power, etc. $[3,34]$ and to suggest efficient methods to reduce these adverse effects. 


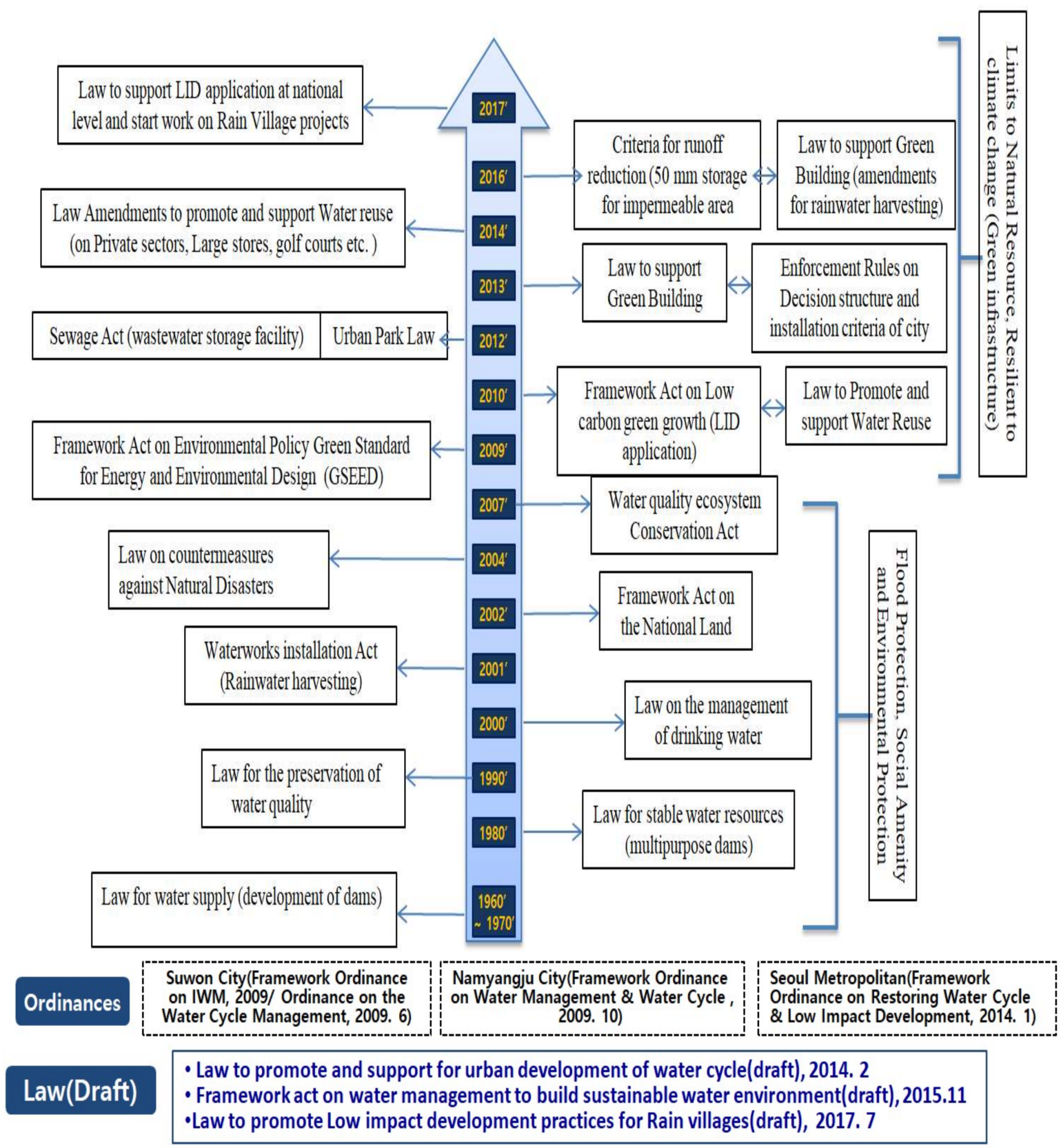

Figure 3. Laws on water-cycle management in South Korea modified from [3].

For rainwater management, a new law on low-carbon green growth was approved in 2010. The main purpose of this law was to install new rainwater-harvesting facilities to utilize rainwater efficiently for gardening etc. In 2010, LID practices were introduced in Korean water law with the main purpose of minimizing water pollution and recovering the natural hydrological cycle of urban areas. Later in 2012, the sewage law was amended for the application of treated wastewater. The definition of a "sewage storage facility" is made to reduce the flood damage, to reduce water pollution, and to reuse sewage water for different purposes such as irrigation and water supply. More efforts were made to enhance LID applications in open spaces such as parks, playgrounds and schools etc. For this purpose, the Urban Parks and Greenery Act was established.

In order to adapt to climate change impacts, a green building certification system was implemented for low-carbon growth in Korea. The main purpose was to make buildings safer, sustainable and more resilient to climate change. The Green Standard for Energy and Environmental 
Design (GSEED), Green Building Act, Article No. 16 was revised in 2013 to include LID practices. The criteria included ratings by using the stormwater-management practices in the Green Standard for Energy and Environmental Design (G-SEED). The rating criteria mark in buildings is explained as follows: the use of stormwater-management practices (such as a green roof, rain garden etc.) will receive 5 credits; the use of rainwater and water infiltrating to ground (rain garden, permeable infiltration trench etc.) will receive 4 credits; the use of water-saving equipment in buildings (rain cistern) will receive 3 credits; the use of equipment for water usage monitoring will receive 2 credits; and the use of gray water and treated wastewater effluent will receive 1 credit.

For water re-use utilization, in 2014 the Promotion and Support of Water Re-use law was approved for the installation of water-management facilities at different places such as apartments, large sales facilities, golf courses, etc. These places have enough space to apply water-management facilities in order to restore water aquifers and re-use water in urban areas. In 2014, the national security agency revised the natural disaster countermeasures law for small-scale development projects, and it was made mandatory to apply LID facilities in specific available areas.

In order to ensure a safe and sustainable city for all, the Ministry of Environment (MoE) also revised the green building certification standards in 2016 and included stormwater management with a new law for LID/GI. The new rules were under the revised Green Standard for Energy and Environmental Design (GSEED) and were named the Construction and Installation Standards. The main purpose of these standards was to minimize the rainwater runoff and discharge to other places [34]. These above rules tried to restore the natural hydrological cycle of the city and also helped in on-site stormwater management in urban areas. In 2016, a new law to support green buildings was established which included these LID facilities applications in urban areas. In 2017, the new laws and acts were established for the LID application on a large scale all around the country. These laws also include the inspection, planning and management of LID practices. The main purpose of this law was to monitor and manage water-resource facilities, to collect useful information for stakeholders and the public, and to prepare future manuals. The legislative work promoting the LID and GI practices in South Korea is still ongoing.

\subsubsection{Local Level}

In order to ensure sustainable development at local level, the Korean government also passed some ordinances for the application of LID practices. For example, Suwon and Namyang cities collaborate, and passed an ordinance on water management. In 2014, the Seoul Metropolitan Government established water-regulation plans that included the application of LID practices at apartments, buildings, roads, parking areas, landscaping, etc. In this ordinance, more focus was given to the application of LID facilities in the Seoul area to recover the natural hydrological cycle. Figure 4 explains the administrative structure of the LID for Seoul Metropolitan area.

Since January 2015, a new construction plan has been specified for Seoul, which includes rainwater-management facilities of an area of more than $1000 \mathrm{~m}^{2}$. If a parking area is wider than $8 \mathrm{~m}$, then LID facilities have to be installed. Along the roadsides, LID facilities such as (i.e., grass swale) should also be included. In this ordinance, the Seoul metropolitan government also focused on the application of LID/GI practices in existing areas and tried to make the city safe, sustainable and resilient to climate change. More work is going on to establish pre-consultation systems and a water-circulation policy advisory organization which may provide useful information for each LID practice such as its purpose, benefits, cost and management phase [34]. This will help lawmakers choose the optimum LID facilities at the desired place to achieve multiple benefits [34]. 


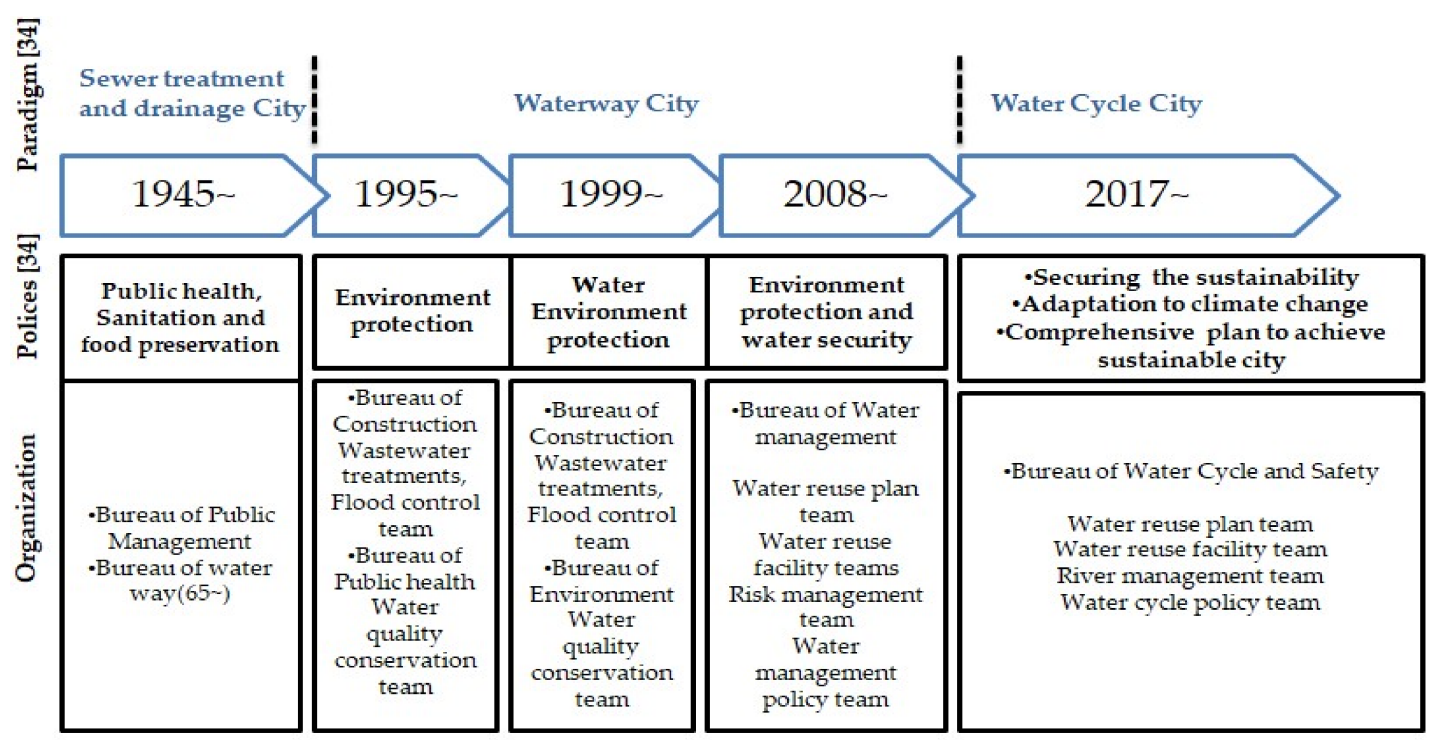

Figure 4. Administrative structure of LID for Seoul Metropolitan [3].

\subsection{Korea LID-Verification Facility}

The Korean LID-verification facility centre was established by the Korean government at Pusan National University, Busan, in 2014. The main purpose of this center is to apply new LID/GI practices and to check long-term research results for future application for LID practices. This new centre was built for promoting LID/GI practices, restoring natural environmental conditions, promoting sustainable stormwater-management facilities, and establishing a system for the government to provide policy incentives for a LID/GI eco-friendly public apartment market while encouraging continual research, development and market application. In this centre, different LID practices were applied at the different locations, and the results of those practices are collected for national verification and standards of LID practices. Figure $5 \mathrm{~b}$ shows the overall details, including the LID experimental labs, LID practice sites, and the Korea LID-verification facility.

Research results were collected from the different LID practices applied at different locations in the Seoul metropolitan area. Results were collected from different storm events of $50 \mathrm{~mm} / \mathrm{h}$ to $120 \mathrm{~mm} / \mathrm{h}$ rainfall intensity [34]. Most of the LID practice designs followed US EPA design guidelines. LID project results showed that LID practices are useful for stormwater management in South Korea as shown below. They also show that these practices are very helpful for controlling rainfall runoff in different rain events. However, there are many challenges at present which may inhibit the long-term success of LID projects. The following section includes the LID practices, research results, challenges and opportunities for the application of LID practices.

\subsection{Seoul Metropolitan LID Project Results for Restoring the Urban Water Cycle}

In South Korea, most of the development has occurred in the capital city, Seoul. The Seoul Metropolitan LID project is one of the biggest national LID project in South Korea, and the authors of this paper are also working on this project. Green roof, green blue roof (combination of the green and blue roof) [35-38], blue roof [36], bioretention, permeable pavements, storage tank, cistern etc. [39] technology is applied at the different sites and the results manifested for stormwater management. The main idea behind these installations is to use different LID practices in a given area to utilize rainwater as much as possible (around $50 \mathrm{~mm}$ /day rainfall). The main purposes of using these LID practices are : (1) improvement of the current water-management system in Seoul; (2) establishment of a comprehensive plan for the healthy water-cycle city; (3) establishment of the basic plan for rainwater management in Seoul where annual rainwater runoff of $620 \mathrm{~mm}$ is to be handled through storage, infiltration and utilization [34]. 


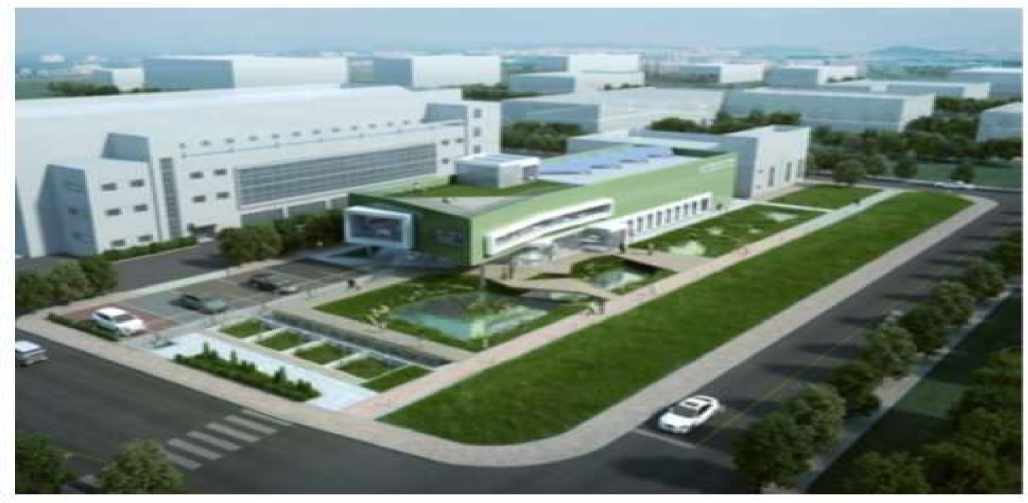

(a)

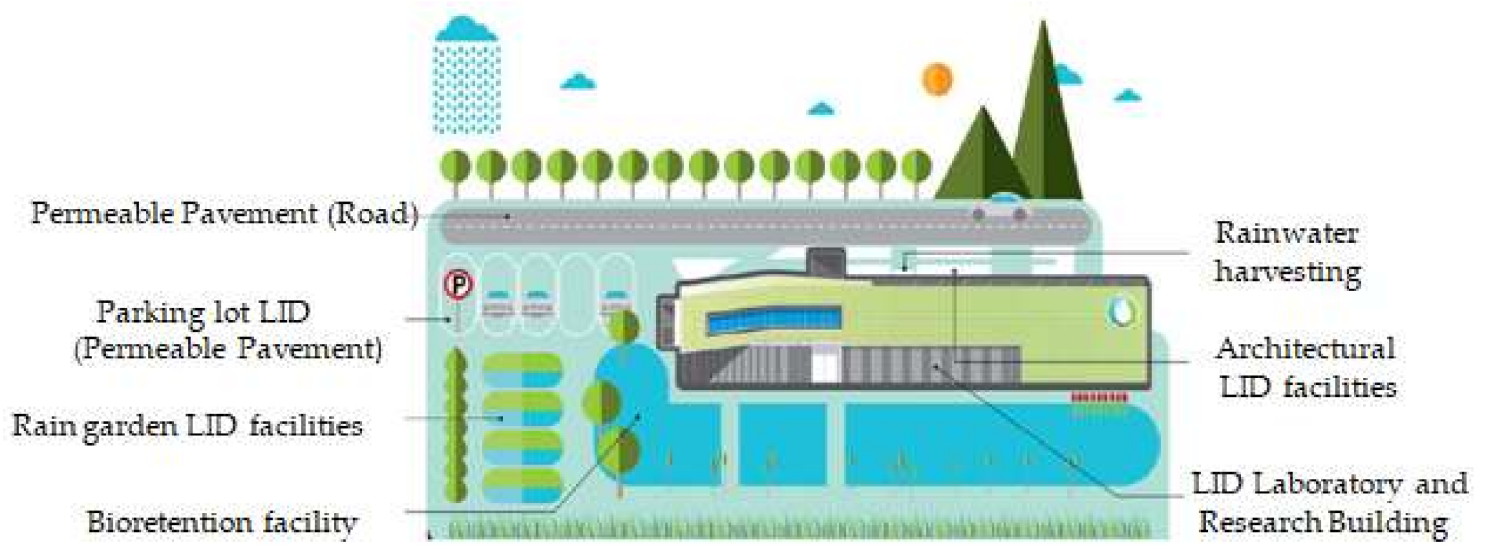

(b)

Figure 5. Korea LID-verification facility at Pusan National University, (a) LID facility centre; (b) detailed overview of the LID-verification facility.

Table 2, shows the LID practice monitoring results for stormwater in different areas [34]. These results were monitored at different LID sites and annual data were collected to check the performance of LID practices for stormwater management in Korean conditions. The monitored results showed that there were around 888 permeable pavements applied over an area of 1,478,492 $\mathrm{m}^{2}$ and total runoff volume reduced was $25,461 \mathrm{~m}^{3} / \mathrm{h}$. Green roof technology was applied at 757 places in the total area of around $332,637 \mathrm{~m}^{2}$ reducing the runoff volume to about $948 \mathrm{~m}^{3} / \mathrm{h}$. Similarly, infiltration trenches, infiltration boxes and cisterns were also applied in different areas of 73,262 $\mathrm{m}^{2}, 6609 \mathrm{~m}^{2}$, and $333,583 \mathrm{~m}^{2}$, respectively. These practices reduced the runoff volume to $4196 \mathrm{~m}^{3} / \mathrm{h}, 1759 \mathrm{~m}^{3} / \mathrm{h}$ and $2784 \mathrm{~m}^{3} / \mathrm{h}$, respectively [34]. The total rainfall runoff volume reduction value of stormwater management, by applying different LID practices in different areas, was $35,823 \mathrm{~m}^{3} / \mathrm{h}$ compared to 2016. Table 2 also shows that there were no research results from the rain garden, filter strip, infiltration tree planter and ecological parking lot. This is because there is less space available for the application of LID practices in a highly urbanized city like Seoul. In addition, underground infrastructure also demands extra care if we want to apply LID facilities in those areas. However, the Seoul government is trying to expand LID projects by applying more LID practices around the country and is expected to reduce around $1276 \mathrm{~m}^{3} / \mathrm{h}$ stormwater in the near future. In future projects, the Seoul government is also including the construction of a rain garden, filter strip, infiltration-tree planters, and an ecological parking lot in the suitable places to achieve multiple benefits. 
Table 2. LID practices applied in the Seoul metropolitan area and their performance in managing the stormwater [34].

\begin{tabular}{|c|c|c|c|c|}
\hline \multirow[b]{2}{*}{ LID Facilities } & \multicolumn{2}{|c|}{$\begin{array}{l}\text { Monitored Results of Applied LID } \\
\text { Facilities [2016] }\end{array}$} & \multicolumn{2}{|c|}{ Expansion Projects of LID Measures } \\
\hline & Number & $\begin{array}{l}\text { Area (Amount of Stormwater } \\
\text { Management } \\
\text { Countermeasure) }\end{array}$ & Number & $\begin{array}{l}\text { Area (Amount of } \\
\text { Stormwater Management } \\
\text { Countermeasure) }\end{array}$ \\
\hline Permeable Pavement & 888 & $1,478,491 \mathrm{~m}^{2}\left(25,136 \mathrm{~m}^{3} / \mathrm{h}\right)$ & 30 & $50,400 \mathrm{~m}^{2}\left(857 \mathrm{~m}^{3} / \mathrm{h}\right)$ \\
\hline Rain Garden & - & - & 3 & $3700 \mathrm{~m}^{2}\left(63 \mathrm{~m}^{3} / \mathrm{h}\right)$ \\
\hline Ecological Parking lot & - & - & 1 & $480 \mathrm{~m}^{2}\left(41 \mathrm{~m}^{3} / \mathrm{h}\right)$ \\
\hline Filter Strip & - & - & 1 & $500 \mathrm{~m}^{2}\left(9 \mathrm{~m}^{3} / \mathrm{h}\right)$ \\
\hline Infiltration Tree Planter & - & - & 3 & $1280 \mathrm{~m}^{2}\left(22 \mathrm{~m}^{3} / \mathrm{h}\right)$ \\
\hline Green Roofs & 757 & $332,637 \mathrm{~m}^{2}\left(948 \mathrm{~m}^{3} / \mathrm{h}\right)$ & 182 & $68,146 \mathrm{~m}^{2}\left(193 \mathrm{~m}^{3} / \mathrm{h}\right)$ \\
\hline Infiltration Trench & 705 & $73,264 \mathrm{~m}\left(4196 \mathrm{~m}^{3} / \mathrm{h}\right)$ & 16 & $320 \mathrm{~m}\left(17 \mathrm{~m}^{3} / \mathrm{h}\right)$ \\
\hline Infiltration Box & 577 & 6609 units $\left(1759 \mathrm{~m}^{3} / \mathrm{h}\right)$ & - & - \\
\hline Rain Barrel & - & - & 301 & $448 \mathrm{~m}^{2}\left(25 \mathrm{~m}^{3} / \mathrm{h}\right)$ \\
\hline Cistern & 494 & $333,583 \mathrm{~m}^{2}\left(3784 \mathrm{~m}^{3} / \mathrm{h}\right)$ & 18 & $706 \mathrm{~m}^{2}\left(40 \mathrm{~m}^{3} / \mathrm{h}\right)$ \\
\hline Total & 3421 & $35,823 \mathrm{~m}^{3} / \mathrm{h}$ & 555 & $1267 \mathrm{~m}^{3} / \mathrm{h}$ \\
\hline
\end{tabular}

Table 3, below shows the characteristics of the LID facilities applied in South Korea. LID practice designs were modified by the authors and applied in the Seoul areas, and the results show that these practices enhance their performance for stormwater management. The research results of LID practices showed that these are useful for handling rainfall runoff in small storm events of $50 \mathrm{~mm} / \mathrm{h}[35,36]$. The above results showed the LID practices are helpful for stormwater management in urban areas. Results from these facilities show tremendous success in controlling a large amount of water in big storm events $[35,36]$. The blue roof is a cost-effective LID practice and used to control stormwater in the case of small rain events [36]. Other LID practice designs followed the same mechanism of the US environmental protection agency (EPA), and their performance is summarized in Table 3.

Table 3. Characteristics of currently applied LID facilities in South Korea.

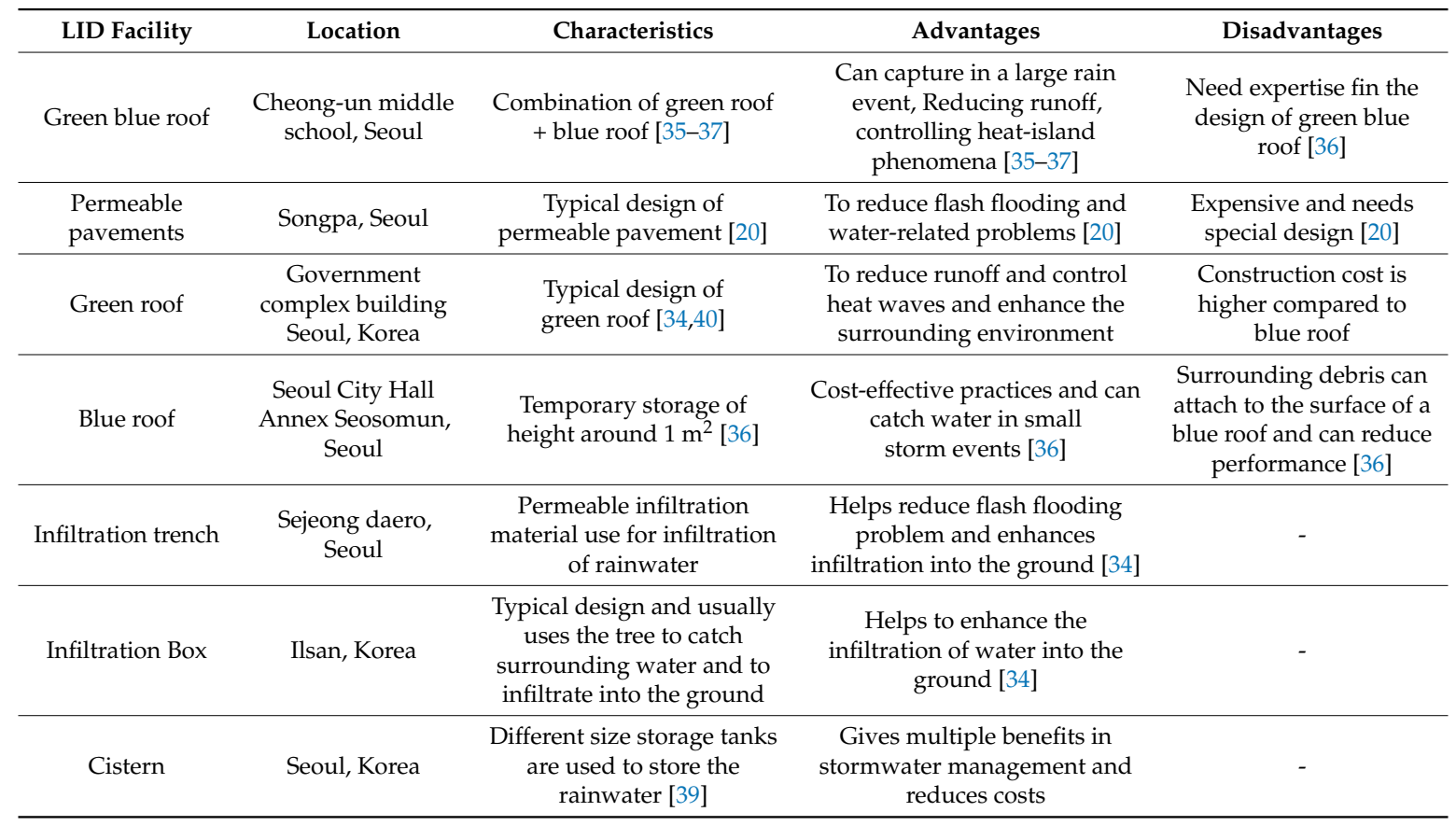

The above showed promising results of LID practices in managing stormwater near the site. However, there are still growing challenges associated with the application and implementation 
of LID/GI practices to mitigate or resolve water-related problems in order to achieve a safe and sustainable city.

\subsection{Challenges for the Application of LID/GI in South Korea}

There are still many challenges for the application of LID practices in South Korea. Data are collected from different papers, reports and public interviews. Different studies were carried out to find out the challenges for the application of LID/GI in South Korea, which are explained below.

\subsubsection{Need for a Special LID/GI Application Plan}

Currently, in South Korea LID practices are mostly focused on the smaller scale such as individual buildings. However, to reduce flash-flooding problems in cities, [40] there is a need to develop a special plan for LID/GI application that can apply to all urban areas. The current water-sewage system that discharges water offsite in a short time also reduces the infiltration of water into the ground and causes a sewage overflow, and hence a need to transform the water-cycle city plan [22,41-46]. Therefore, continued research results need to be provided to the public in order to diminish these issues.

\subsubsection{Lack of Regulation on the Planning and Implementation of LID/GI in South Korea}

Appropriate regulations for applying LID facilities are necessary for its success. There is still a lot of work required to make proper rules and regulations in Korea. Currently, LID/GI practices are applied in different cities; however, there are still no specific rules for the management of LID practices which is one the biggest challenges to date $[22,43,44,46]$. The management of LID practices means asking questions about who will take care of the LID practices after construction, i.e., the house owner, local authority etc. For the successful application of low-impact development for multiple benefits there is a need to provide management laws and regulations.

\subsubsection{Lack of Inter-Agency Collaboration and Cooperation}

Lack of collaboration and cooperation in the application of LID/GI facilities is the biggest problem in Korea. This is because for the implementation of LID projects, most of the sectors do not agree as LID facilities have high initial costs $[3,45,46]$. There is no general cooperation between different professional spheres (civil engineers, transportation engineers and environmental engineers) for the application of LID/GI practices.

\subsubsection{Lack of Knowledge and Inappropriate Designs}

Lack of skilled labor for the construction of different LID facilities, i.e., permeable pavements and the green roof, is another issue in Korea. Firstly, the labor costs are high as compared to China, Taiwan and other Asian countries that also demand significant levels of capital for the application of LID practices. We know that if LID practices are not well constructed or applied properly, then they may require special maintenance to perform at a desirable level $[35,47,48]$. Lack of knowledge and guidance, design standards as well as inexperienced planners may result in the unsuccessful development of LID/GI practices [48-50]. For example, a rain-harvesting storage tank is compulsory in building design for rainwater in Korea. The main concept of this idea is to store the rainwater and to use it for other purposes (such as irrigating nearby areas etc.). However, this system cannot run without energy because the energy is required to pull water from the storage tank to irrigation places. Therefore, there is a high need for more expertise to design different LID practices that will give multiple benefits in urban areas.

\subsubsection{Unavailability of Green Product}

LID industry has been booming in the US and some of the European countries during the past few decades. Most of the products and materials required for this industry have been developed and 
provided only by these countries [29]. These green products also include geo-membrane materials etc. which are mostly used in the green roof and rain garden [37]. In South Korea, LID/GI products currently are imported from foreign countries. Therefore, an absence of local green products increases the construction cost and may also greatly hinder the expansion of LID/GI in Korea [37].

\subsubsection{Ambiguity of Life-Cycle Costs and Benefits}

Research on LID/GI facilities is still in progress and there are few studies that show the life-cycle costs of these LID facilities [16]. In addition, the life-cycle cost and benefits (environmental, social and ecological) are also unknown [22,29,42]. For LID facilities' application, there are specific costs for the operation and maintenance of LID practices which are still unknown. Under these circumstances, the participation of stakeholders in LID/GI projects is also a major challenge.

\subsubsection{Lack of Incentives for the Application of LID Practices in South Korea}

Lack of incentives to the public for the application of LID practices in South Korea is a major challenge. There are no such incentives to homeowners for the application of LID practices which encourage them to apply LID practices.

\subsubsection{Existing Infrastructure do not Allow Application in Big Cities}

Sometimes it is very difficult to find space for the application of LID practices in existing developed areas. This is because most of the big cities are highly developed and this also makes it difficult to find the space for the application of LID practices in South Korea.

\subsubsection{Lack of Knowledge of the Management of LID Practices}

In South Korea, most of the LID practices are not managed well by the public or homeowner. This greatly affects the performance of LID practices over a long period of time. For example, a green roof cannot perform well for water-quality improvement just after construction. This is because the homeowner uses more fertilizer in the green roof soil and this affect its performance.

\subsection{Future Opportunities for LID/GI Application in Korea}

\subsubsection{Innovative and Systematic Approach to LID/GI Application}

First and foremost, LID/GI application requires systematic and innovative thinking at all stages (i.e., planning, constructing, implementing and managing) [51,52]. The main issues facing LID/GI application are usually water-related problems such as stormwater management, drought and water pollution. These problems could be solved by a systematic approach for managing urban water as in some related work that has been carried out in Canada [48,49]. Credit Value Conservation (CVC) 2015 [49] worked on the development of new sustainable approaches to adopt LID practices that can provide multiple benefits in urban areas. But, there is still a need to develop new guidelines for the application of LID practices under Korean climatic and geographic conditions.

\subsubsection{Financial Incentives for the Application of LID in South Korea}

To promote LID practices on a larger scale, there is a need to provide financial incentives to the pubic, house owners and stakeholders. This will not only attract people to adopt LID applications, but will also help to make cities safe and sustainable. The South Korean government should encourage stakeholders in the application of LID practices in new construction by giving them some incentives.

\subsubsection{Design Team Education Programs}

There is a need to design education programs in universities to make people aware of the new climate change regimes as well as new sustainable practices. For this purpose, there is need to have a 
special curriculum in Korean universities on new smart and sustainable cities. There also a need to organize seminars and public meeting to tell them about the importance of LID application by showing them some successful case studies in other countries.

\subsubsection{Innovative Policies}

The South Korean government should establish innovative policies in order to make cities as new smart and sustainable cities. For this, there is significant need to establish some specific policies for the application of LID practices for all new construction projects. Moreover, this policy should not only be adopted at the national level but also at the local level.

\subsubsection{Strengthening Scientific Research to Create New Innovative LID/GI Tools}

Advanced research and in-depth applications of studies into the LID/GI concept and practices are needed in order to develop a new innovative design tool specifically for Korean conditions. This is because most LID guideline i.e., CVC, Edmonton, have been applicable in cold climates such as Canada, the USA, and European countries. However, in Asian countries where the climatic conditions are different as the summer temperature is hot these cannot yield useful results [50,52]. Therefore, there is a need for separate guidelines which may also include Asian weather conditions for the application of LID practices in these countries. In South Korea, at the national level, there is a significant need to develop the new models, designs, maintenance and operation guidelines and to establish a national database for LID/GI cities [22,31]. At the local level, there is also a need to inform the public about the benefits of LID/GI facilities, their impacts on watersheds, and to provide the incentives to encourage LID cities; conducting triple bottom line (environment, social and economic) analysis to identify the benefits of LID/GI facilities. Figure 6, shows that in South Korea there is still a need to draw up plans for road and parking areas for LID applications. Moreover, the development of a new innovative tool that will help to find the optimal place and life-cycle cost for each LID facility is required [29,31,53].

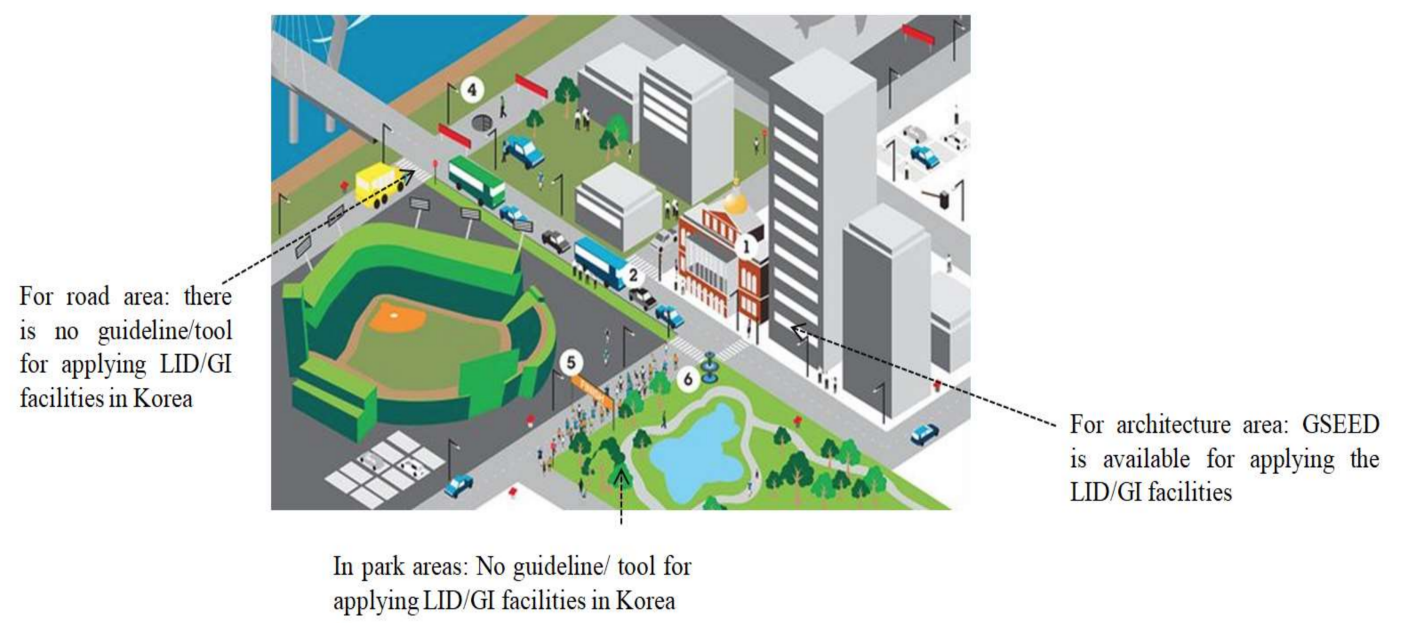

Figure 6. Sites where new guidelines/tools are needed for the application of LID/GI in Korea (authors' illustration).

\subsubsection{Enhancing the Urban Monitoring System}

For monitoring LID/GI facilities, it is better to utilize the Internet of Things (IOT) in many aspects of urban water management. Smart devices for drainage and rainwater collection could be installed that can give useful online information to users. Additionally, online and real-time monitoring, including rainfall runoff and precipitation amounts in the drainage and urban surfaces in urban areas, is also essential $[22,46]$. This can help to forecast flooding and to mitigate other future water-related problems in urban areas. 


\subsubsection{New Innovative Urban Water-Management System}

There is a need to change our traditional urban water-management system to a new, innovative urban water-management system by using cost-effective LID/GI facilities [22,30,44-47]. In the new system, there is a need to demonstrate and identify the proper areas for the application of LID facilities. These sites and LID practices should be selected very carefully in order to develop a sustainable city. Moreover, the development of a more cost-effective LID facility that can provide multiple benefits in an area is also required $[50,53]$.

\subsubsection{Strengthening Co-Operation and Collaboration}

Co-operation and collaboration among different stakeholders is important and necessary for the successful application of LID/GI facilities for safe and sustainable cities. As we know, LID application requires a high budget and significant care for its successful implementation $[16,22]$ Therefore, there is a need for public-private partnerships (PPP) for the expansion of LID concept knowledge and expansion throughout the country [22,31]. Government agencies should work together to identify the current challenges and for the expansion of LID facilities to transfer our gray cities into green cities. These stakeholders should collaborate to change current municipal codes and other standards and make some ordinance for the expansion of the LID project all around the country. This work can be done by following the US (EPA) 2014 [52] collaborative support document in which they discussed in detail co-operation and collaboration in LID construction in the US. In Korea, there is also a significant need to prepare such collaborative guidelines that can provide a comprehensive strategy to divide the LID construction tasks among different fields. At the local level, it is necessary to make the public aware of the importance of LID projects for urban cities. At the international level, there also needs to be co-operation and collaboration to share knowledge, experience and products through international workshops, seminars and conferences. This can be done to adopt the advanced level research, methods, new cost-effective approaches related to stormwater management emanating from the US, Europe and Japan. An enormous effort is needed globally to develop more cost-effective LID facilities that can offer multiple benefits [49-53]. Figure 7 explains the steps for strengthening collaboration for the application of LID practices from the local to the global level. In step 1, it shows that there should be a collaboration at local level for the application of LID practices. Step 2 and 3 explains that there should a platform where multiple national and international experts meets and share useful information about the importance of LID practices.

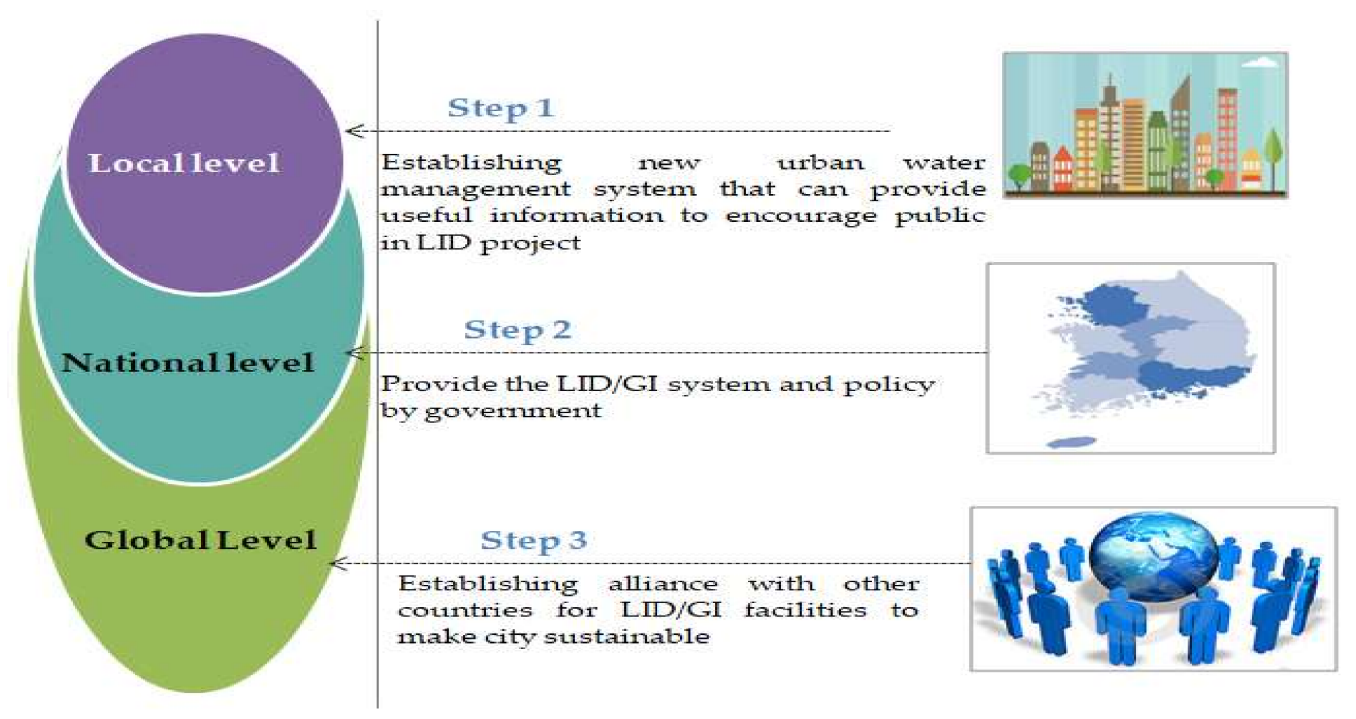

Figure 7. Steps for strengthening collaboration from the local to the global level based on Seoul Metropolitan project results (authors' illustration). 


\section{Conclusions}

Low-impact development (LID) practices are gaining greater importance as a result of the increased acknowledgement of the positive effects of mimicking natural hydrology around the globe. This paper provides an overview of water-circulation policy development in South Korea. It explains the local water policy amendments for making cities safer and more sustainable in South Korea. It also presents multiple LID/GI experiences applied in other countries for safe and sustainable stormwater management.

Despite the advantages of LID/GI techniques for sustainable stormwater management, the application of LID/GI is still a major challenge in reality in South Korea. The lack of financial support and cooperation and collaboration between different engineering professional spheres (civil engineers, environmental engineers, water-resource engineers and transportation engineers) are the biggest challenges for the expansion of LID/GI projects in Korea. However, there is still a need to explore new opportunities for safer and more holistic urban cities. Based on the study, the following conclusions were drawn:

- Diverse and huge efforts are needed to explore the multiple benefits of LID/GI facilities that can encourage the general public to participate in LID projects.

- There is a need for more research to find more cost-effective, optimal combinations of LID practices that can have multiple benefits in the Korean geographical context.

- At the national level, LID/GI concepts should be included in the law and should be implemented in all development projects.

- More cooperation and collaboration is needed at the local, national and international levels to share knowledge, technology transfer and to find new innovative design/tools for LID/GI projects.

With the appropriate guidelines and laws, the obstacles can be minimized, resulting in fewer barriers to the implementation of LID practices. In future, there is a need to merge more innovative, cost-effective LID/GI practices in order to enhance their synergy to achieve multiple benefits (social, environmental and economic).

Acknowledgments: This research is supported by a grant (15technology innovationC04) from the Advanced Water Management Research Program funded by the Ministry of Land, Infrastructure and Transport of the Korean government.

Author Contributions: The paper was guided by Reeho Kim. Muhammad Shafique analyzed the results and arranged the manuscript. The whole manuscript was composed and written by Muhammad Shafique.

Conflicts of Interest: The authors declare no conflict of interest.

\section{References}

1. Elliott, A.H.; Trowsdale, S.A. A review of models for low impact urban stormwater drainage. Environ. Model. Soft. 2007, 22, 394-405. [CrossRef]

2. Todeschini, S. Hydrologic and environmental impacts of imperviousness in an industrial catchment of northern Italy. J. Hydrol. Eng. 2016, 21, 05016013. [CrossRef]

3. Kim, R. Low Impact Development and Green Infrastructure in South Korea: Trends and Future Directions. Ecol. Resilient Infrastruct. 2016, 2, 80-91. (In Korean) [CrossRef]

4. Korea Meteorological Administration, Seoul, Korea(KMA). The Most Mortality of Meteorological Disasters Is Due to the Heat Wave. Available online: http:/ / web.kma.go.kr/notify / press/kma_list.jsp?bid=press\& mode=view\&num=1192407 (assessed on 1 April 2016). (In Korean)

5. Kysely, J.; Kim, J. Mortality during heat waves in South Korea, 1991 to 2005: How exceptional was the 1994 heat wave? Clim. Res. 2009, 38, 105-116. [CrossRef]

6. Lee, E. Status of agricultural water resources and case of drought measures. Water Future 2015, 48, 62-71. (In Korean) 
7. Kim, Y.H.; Yourim, Y. Spatiotemporal pattern networks of heavy rain among automatic weather stations and very-short-term heavy-rain prediction. Adv. Meteorol. 2016, 2016. [CrossRef]

8. MOLIT. Last Year, 91.66\% Live in Urban Areas. Ministry of Land, Infrastructure and Transport, Sejong, Korea. 2015. Available online: http:/ / molit.go.kr/USR/NEWS/m_71/dtl.jsp?lcmspage=56\&id=95076009 (assessed on 1 April 2016). (In Korean)

9. The World Dank Development, IBRD·IBA. Urban Development. Available online: https:/ / data.worldbank. org/topic/urban-development?end=2016\&locations=KR-CN-US\&start=1989 (assessed on 7 September 2017).

10. Newcomer, M.E.; Gurdak, J.J.; Sklar, L.S.; Nanus, L. Urban recharge beneath low impact development and effects of climate variability and change. Water Resour. Res. 2014, 50, 1716-1734. [CrossRef]

11. Dietz, M.E.; Clausen, J.C. Stormwater runoff and export changes with development in a traditional and low impact subdivision. J. Environ. Manag. 2008, 87, 560-566. [CrossRef] [PubMed]

12. Damodaram, C.; Giacomoni, M.H.; Prakash, K.C.; Holmes, H.; Ryan, A.; Saour, W.; Zechman, E.M. Simulation of combined best management practices and low impact development for sustainable stormwater management. J. Am. Water Resour. Assoc. 2010, 46, 907-918. [CrossRef]

13. Jeon, J.H.; Lim, K.J.; Choi, D.H.; Kim, T.D. Modeling the effects of low impact development on Runoff and Pollutant Loads from an Apartment complex. Environ. Eng. Res. 2010, 15, 167-172. [CrossRef]

14. Jeong, J.; Kannan, N.; Arnold, J.G.; Glick, R.; Gosselink, L.; Srinivasan, R.; Barrett, M.E. Modeling sedimentation-filtration basins for urban watersheds using Soil and Water Assessment Tool. J. Environ. Eng. 2013, 139, 838-848. [CrossRef]

15. Kim, R. Policies of water cycle management in Korea and necessity of development of Korean low impact development technologies. Water Future 2014, 47, 16-21.

16. Shafique, M.; Reeho, K. Retrofitting the Low Impact Development Practices into Developed Urban areas Including Barriers and Potential Solution. Open Geosci. 2017, 9, 240-254. [CrossRef]

17. Guo, C.Y. Preservation of watershed regime for low impact development. J. Hydrol. Eng. 2009, 15, 15-19. [CrossRef]

18. Wright, T.J.; Liu, Y.; Carroll, N.J.; Ahiablame, L.M.; Engel, B.A. Retrofitting LID actices into Existing Neighborhoods: Is It Worth It? Environ. Manag. 2016, 57, 856-867. [CrossRef] [PubMed]

19. Danfoura, M.N.; Gurdak, J.J. Redox Dynamics and Oxygen Reduction Rates of Infiltrating Urban Stormwater beneath Low Impact Development (LID). Water 2016, 8, 435-447. [CrossRef]

20. Ahiablame, L.M.; Engel, B.A.; Chaubey, I. Effectiveness of low impact development practices: Literature review and suggestions for future research. Water Air Soil Pollut. 2012, 223, 4253-4273. [CrossRef]

21. Hunt, W.F.; Traver, R.G.; Davis, A.P.; Emerson, C.H.; Collins, K.A.; Stagge, J.H. Low impact development practices: Designing to infiltrate in urban environments. In Effects of Urbanization on Groundwater: An Engineering Case-Based Approach for Sustainable Development; American Society of Civil Engineers: Reston, VA, USA, 2010; pp. 308-343.

22. Shafique, M.; Reeho, K. Green stormwater infrastructure with low impact development concept: A review of current research. Desalination Water Treat. 2017, 83, 16-29. [CrossRef]

23. Fassman, E.A.; Blackbourn, S. Urban runoff mitigation by a permeable pavement system over impermeable soils. J. Hydrol. Eng. 2010, 15, 475-485. [CrossRef]

24. Fletcher, T.D.; Shuster, W.; Hunt, W.F.; Ashley, R.; Butler, D.; Arthur, S.; Trowsdale, S.; Barraud, S.; Semadeni-Davies, A.; Bertrand-Krajewski, J.L.; et al. SUDS, LID, BMPs, WSUD and more-The evolution and application of terminology surrounding urban drainage. Urban Water J. 2015, 12, 525-542. [CrossRef]

25. Lloyd, S. Water Sensitive Urban Design in the Australian Context; Cooperative Research Centre for Catchment Hydrology: Melbourne, Australia, 2001.

26. Brown, R.; Keath, N.; Wong, T. Transitioning to water sensitive cities: Historical, current and future transition states. In Proceedings of the 11th International Conference on Urban Drainage, Edinburgh, Scotland, 31 August-5 September 2008.

27. Barton A, B.; John, R.A. A review of the application of water sensitive urban design (WSUD) to residential development in Australia. Australas. J. Water Resour. 2007, 11, 31-40. [CrossRef]

28. Jackson, J.I.; Boutle, R. Ecological functions within a sustainable urban drainage system. In Proceedings of the 11th International Conference on Urban Drainage, Edinburgh, Scotland, 31 August-5 September 2008. 
29. Xia, J.; Zhang, Y.; Xiong, L.; He, S.; Wang, L.; Yu, Z. Opportunities and challenges of the Sponge City construction related to urban water issues in China. Sci. China Earth Sci. 2017, 60, 652-658. [CrossRef]

30. Li, L.H.; Ding, L.; Ren, M.; Li, C.; Wang, H. Sponge city construction in China: A survey of the challenges and opportunities. Water 2017, 9, 594. [CrossRef]

31. Zhou, Q. A review of sustainable urban drainage systems considering the climate change and urbanization impacts. Water 2014, 6, 976-992. [CrossRef]

32. Oh, B.H. Modularization of Korea's Development Experience: Korea's River Basin Management Policy; Korea Development Institute School of Public Policy and Management: Seoul, Korea, 2013.

33. Lee, S.; Choi, G.W. Governance in a river restoration project in South Korea: The case of Incheon. Water Resour. Manag. 2012, 26, 1165-1182. [CrossRef]

34. Seoul Metropolitan. Stormwater Master Plan-Seoul Metropolitan; Seoul, Korea, 2016. (In Korean)

35. Shafique, M.; Kim, R. Application of green blue roof to mitigate heat island phenomena and resilient to climate change in urban areas: A case study from Seoul, Korea. J. Water Land Dev. 2017, 65, 165-170.

36. Shafique, M.; Daehee, L.; Reeho, K. A Field Study to Evaluate Runoff Quantity from Blue Roof and Green Blue Roof in an Urban Area. Int. J. Control Autom. 2016, 9, 59-68. [CrossRef]

37. Shafique, M.; Reeho, K.; Lee, D. The Potential of Green-Blue Roof to Manage Storm Water in Urban Areas. Nat. Environ. Pollut. Technol. 2016, 15, 715-718.

38. Shafique, M.; Daehee, L.; Reeho, K. Roof Runoff Control by Using the Green Blue Roof and Blue Roof in the Urban Area. Adv. Sci. Technol. Lett. 2016, 136, 18-21.

39. Lee, S.W.; Kim, R. Application of Benefit Assessment to Infiltration Storage Tank and Permeable Pavement Demonstrated in Seoul Metropolitan, Korea. Int. J. Hybrid Inf. Technol. 2016, 9, 411-422. [CrossRef]

40. Shafique, M.; Kim, R.; Kyung-Ho, K. Green Roof for Stormwater Management in a Highly Urbanized Area: The Case of Seoul, Korea. Sustainability 2018, 10, 584. [CrossRef]

41. Shafique, M.; Kim, R.; Kyung-Ho, K. Evaluating the Capability of Grass Swale for the Rainfall Runoff Reduction from an Urban Parking Lot, Seoul, Korea. Int. J. Environ. Res. Public Health 2018, 15, 537. [CrossRef] [PubMed]

42. Paek, S.; Gil, K. Effects of Grassed Swale Lengths on Reduction Efficiencies of Non-point Source Pollutants. J. Wetl. Res. 2013, 15, 387-396. [CrossRef]

43. Bowman, T.; Thompson, J. Barriers to implementation of low-impact and conservation subdivision design: Developer perceptions and resident demand. Landsc. Urban Plan. 2009, 92, 96-105. [CrossRef]

44. Godwin, D.; Parry, B.; Burris, F.; Chan, S.; Punton, A. Barriers and Opportunities for Low Impact Development: Case Studies from Three Oregon Communities; Oregon Sea Grant: Corvallis, OR, USA, 2008.

45. Frederick, R.R.; Fernando Pasquel, H.; Loftin, J. Overcoming Barriers to Implementation of LID Practices. In Low Impact Development Technology: Implementation and Economics: LID: Implementation and Economics; American Society of Civil Engineers: Reston, VA, USA, 2015.

46. Jia, H.; Yao, H.; Shaw, L.Y. Advances in LID BMPs research and practice for urban runoff control in China. Front. Environ. Sci. Eng. 2013, 7, 709-720. [CrossRef]

47. Bergman, B. Sustainable Water Practices at Pomona's Parks: Improving Irrigation Use and Stormwater Runoff Retention; California State Polytechnic University, Pomona: Pomona, CA, USA, 2013.

48. Edmonton. Low Impact Development Construction, Inspection \& Maintenance Guide. May 2016. Available online: https:/ / www.edmonton.ca/city_government/documents/LID\%20CIM\%20Guide.pdf (assessed on 21 November 2017).

49. CVC, Credit Value Conservation. Advancing Low Impact Development as a Smart Solution for Stormwater Management. 2015. Available online: http://www.creditvalleyca.ca/wp-content/uploads/2015/07/ Advancing-Low-Impact-Development-as-a-Smart-Solution-for-Stormwater-Management-v1.pdf (assessed on 1 November 2017).

50. Chau, H.F. Green Infrastructure for Los Angeles: Addressing Urban Runoff and Water Supply through Low Impact Development. Ph.D. Thesis, Global Georgetown University, Washington, DC, USA, 2009.

51. Foster, J.; Lowe, A.; Winkleman, S. The value of green infrastructure for urban climate adaptation. Center Clean Air Policy 2011, 750, 1-52. 
52. USEPA (US Environmental Protection Agency). Green Infrastructure Collaborative Statement of Purpose. 2014. Available online: https://www.epa.gov/sites/production/files/201510/documents / greeninfrastructure_collaborative2014_0.pdf (assessed on 10 November 2017).

53. Driscoll, C.T.; Eger, C.G.; Chandler, D.G.; Davidson, C.I.; Roodsari, B.K.; Flynn, C.D.; Lambert, K.F.; Bettez, N.D.; Groffman, P.M. Green Infrastructure: Lessons from Science and Practice; Science Policy Exchange: Petersham, MA, USA, 2015. 